million tons of basic slag, and a quarter of a million tons of ammonium sulphate. The capacity for the production of high explosive was in March, I9I7, more than four times that of March, I9I6, and twenty-eight times that of March, rgi5.

\section{DR. ROBERT BELL, F.R.S.}

$\mathrm{D}^{\mathrm{R}}$ R. ROBERT BELL, who died at Ottawa on June ${ }^{9}$, was one of the pioneers in the geographical and geological exploration of Canada. Born at Toronto on June 3, I84I, he studied natural science and medicine at McGill and Edinburgh Universities, and graduated both as M.D. and as D.Sc at the former university. In ${ }^{8} 857$ he joined the Geological Survey of Canada, of which he became assistant director and eventually acting director shortly before his retirement. In the early part of his career he was also for a short time (1863-68) professor of chemistry and geology in Queen's University, Kingston, Ont.

Dr. Bell's most important work was the exploration and mapping of both sides of Hudson Bay and the Straits, and of the rivers entering Hudson Bay from the south. He also conducted the first surveys of Great Slave Lake, Lake Nipigon, and several other inland waters. As a geologist he paid special attention to the oldest rocks of the Laurentian and Huronian periods, but also made valuable contributions to our knowledge of the Pleistocene glacial deposits of Canada. As a naturalist he was a keen and skilled observer in many directions, but was especially interested in matters concerning forestry. As a medical man his services were at the disposal of several expeditions. Most of his reports were published officially by the Canadian Geological Survey and bear witness to the thoroughness of his researches; while many papers on more general questions were contributed by him to various societies and journals.

Dr. Bell was one of the original fellows of the Royal Society of Canada, and was elected a fellow of the Royal Society of London in 1897 . He received the honorary degree of Sc.D. from the University of Cambridge, and in 1906 he was awarded the Patron's medal by the Royal Geographical Society. In 1906 he also received the Cullum gold medal from the American Geographical Society.

\section{NOTES.}

THE Times correspondent reports the discovery of the skeleton of a mammoth, in association with flint implements, in the neighbourhood of Bapaume, within the lines of the British Army in France. We understand that the British Commander-in-Chief has communicated the fact to the French Government, and that steps have been taken to preserve the specimen until the line of battle is sufficiently far removed to allow of careful excavations being made. The deposit in which the skeleton occurs has already yielded fragmentary remains of the mammoth.

NO. 2488, VOL. 99]
IN reply to a question about the suspension of the publication of the Kew Bulletin, asked by Sir W. Byles in the House of Commons on June $26, \mathrm{Mr}$. Prothero said that the matter was now being reconsidered by the Publications Committee at the request of the Board of Agriculture. He hoped it might prove possible to resume publication.

We regret to see the announcement of the death at Brussels, in his fifty-third year, of Prof. H. Van Laer, professor of chemistry at Mons, and president of the Chemical Society of Belgium.

News has just reached this country of the death on June 2, at Pusa, Bihar, of Prof. J. H. Barnes, Agricultural Chemist to the Goyernment of India, and late principal of the Government College of Agriculture, Lyallpur, Punjab; and also of Prof. E. G. Hill, principal of Muir College, University of Allahabad.

Lieut. J. B. Jones, whose death in action on May $3 \mathrm{I}$, at twenty-six years of age, is announced, was educated at the University College of Wales, Aberystwyth, and was a B.Sc. in chemistry, physics, mathematics, and geologv; he was student-assistant in geology at the above college, and had assisted in the Greological and Soil Survey of West Wales.

Announcement is made in the Times that the Government has been reluctantly forced to the conclusion that it will be impossible to pass a Bill establishing a Ministry of Health during the present session of Parliament. It is possible that the measure may be introduced in the House of Lords, and certain steps taken which will facilitate its progress next session.

THE list of pensions granted during the year ended March $3 \mathrm{I}$ last, and payable under the provisions of the Civil List Act, Ig Io, includes the following :-Mrs. Charlton Bastian, in consideration of the services to science of her late husband, Dr. Charlton Bastian, and of her straitened circumstances, rool.; Mrs. Minchin, in consideration of the scientific work of her late husband, Prof. E. A. Minchin, and of her straitened circumstances, $75 l . ;$ Mrs. Albert Günther, in consideration of the scientific work of her late husband, Dr. Albert Günther, and of his distinguished services to the British Museum as keeper of zoology, $70 l$; and Mrs. Roland Trimen, in consideration of the eminent services of her late husband to biological science, and of her straitencd circumstances, $75 l$.

By the death of Sir George Birdwood, on June 28 , at the age of eighty-four, the Anglo-Indian services have lost a notable personality. He joined the Indian Medical Service in 1854 , and after taking part in the expedition to the Persian Gulf, he was appointed to a professorship in the Grant Medical College at Bombay, which was destined to be the scene of his Indian official life. He cultivated friendly relations with all classes of natives, and contributed to the Times of India. Finally, after serving as Sheriff of Bombay, his health broke down, and he left India in I868, never to return. His administrative ability and fine taste in Indian art secured him a post at the India Office, where he was occupied in organising several exhibitions in which Oriental arts and crafts took a prominent place. For these services he was rewarded with a knighthood and the order of K.C.I.E. His scientific reputation rests on his work on the flora of Bombay, and his researches into the varieties of Boswellia and other sources of Oriental gums and resins. He left few contributions to literature of permanent value, but he was a clever journalist, able to discuss many subjects with wit and vivacity, though his viervs 